\title{
Biopolymer catalysed synthesis of 6-methyl-4-phenylcarbamoyl-1, 2, 3, 4- tetrahydropyrimidine-2-ones and evaluation of their anti-bacterial and anti-tubercular activities
}

\author{
Vasant Chabukswar ${ }^{a^{*}}$, Kalpana Handore ${ }^{\mathrm{a}}$, Suresh Shisodiaa ${ }^{\mathrm{a}}$ Balasaheb Diwate ${ }^{\mathrm{a}}$, Pravin Adhav ${ }^{\mathrm{a}}$, \\ Digamber Pawar ${ }^{\mathrm{a}}$, Swati Jagdale ${ }^{\mathrm{b}}$, Aniruddh Chabukswar ${ }^{\mathrm{b}}$, Sabrina Dallavalle ${ }^{\mathrm{c}}$. \\ ${ }^{a}$ Department of Chemistry, Nowrosjee Wadia College, (S. P. Pune University), 19, Joag Path, Pune -411001, India. \\ ${ }^{b}$ MAEER's Maharashtra Institute of Pharmacy, Kothrud, Pune -411038, India. \\ ${ }^{c}$ DeFENS, Department of Food, Environmental and Nutritional Sciences, Università degli Studi di Milano, Milano, \\ Italy.
}

\begin{abstract}
An efficient one pot biocatalysed ultra sound assisted synthesis of dihydropyrimidinones/thiones has been developed under solvent free conditions. The use of biodegradable, non toxic, agar-powder as a catalyst provides advantages like high yield, simple operation, mild reaction condition, short reaction time under ultrasonic condition. 1,2,3,4-tetrahydropyrimidine-2-ones/thiones formed were characterized by mass and ${ }^{1} \mathrm{H}$ NMR spectroscopy. The dihydropyrimidinones substituted with electron donating groups like fluorine, thiophene aldehyde, methoxy and hydroxy groups showed good antibacterial activity. The compounds were also evaluated for antitubercular activity. The compounds gave favorable binding interactions with mycobacterium target protein H37Rv. Among the tested compounds only 4-methoxy substituted dihydropyrimidinones derivative showed significant anti-tuberculosis activity.
\end{abstract}

Keywords: biocatalysed synthesis, solvent free, green chemistry, antibacterial activity, anti tubercular activity.

\section{INTRODUCTION}

3,4 dihydropyrimidinone/thiones (DHPM) and their derivatives are of significant importance as they possess a wide range of pharmacological activities such as anticancer, antiviral, antihypertensive, antitubercular, anti-inflammatory, calcium blocker, $\alpha$-1a-antagonist, and neuropeptide Y (NPY) antagonist [1-5]. Pyrimidinone derivatives are found as core units in many marine alkaloids like batzelladine and carambine, which have been found to be potent HIV-gp-120 CD4 inhibitors [6-8].

Treatment of infectious diseases is very challenging due to toxicity of existing molecules and resistance problems. Every year, approximately 8-9 million cases of infected people develop clinical pulmonary tuberculosis leading to nearly 2 million annual deaths. A large portion of budget is spent by developing countries to control epidemic diseases. Since 1960 two drugs, isoniazid and rifampicin, have been used as standard for tuberculosis treatment. However, extensive use of these drugs led to insurgence of drug resistance. Presently, multi-drug resistant tuberculosis has put forth a major challenge in the treatment of patients suffering from tuberculosis and infectious diseases.

*Address correspondence to this author at the Department of Chemistry, Nowrosjee Wadia College, Pune, affiliated to Savitribai Phule Pune University, Pune. P.O. Box: 411001, Pune, India; Tel +919960125609, Fax +912026169108; E-mails: vvchabuk@yahoo.com
Thus, there is a urgent need to explore new molecules to effectively fight against infectious diseases.

Dihydropyrimidinones can be considered useful scaffolds for the development of bioactive molecules. [9-12]. Several synthetic protocols have been reported for the synthesis of DHPM using mesoporous, organosilica, titanium silicate, iron chloride, $\mathrm{FeCl}_{3}$, Iron(III) tosylate, $\mathrm{BF}_{3}, \mathrm{Yb}(\mathrm{OTf})_{3}$, Zeolite and L-Proline. Recently, increasing interest has arosen towards ecofriendly, nontoxic and sustainable catalysts. In this regard, biopolymer catalyzed synthesis has emerged as a useful tool to reduce the waste production and use of harsh, toxic chemical catalysts. Recently, heterogeneous catalyst, solid supported method have been used to improve the drawback of previously reported methods. Biopolymers like chitosan, Baker's yeast, starch and cellulose have been used as catalyst for DHPM synthesis due to fast degradation and nontoxic nature of these compounds [13-23].

Agar is naturally obtained from red algae and isolated as a powder formed by boiling. It is a mixture of two components: the linear polysaccharide agarose, made up of the repeating monomer unit of agarobiose[23], and a heterogeneous mixture of smaller molecules called agaropectin, gluconic acid and amino acids. Agar catalyst offers a unique set of environmentally benign properties such as naturally availability, inertness and stability. 
The present work reports the efficient use of commercially available agar as a biodegradable, ecofriendly catalyst for one-pot, three-components Biginelli's reaction under solvent-free conditions. Effect of substituent, reaction time, loading of catalyst, yield; and the efficiency of the agar catalyst are also studied. To the best of our knowledge, agaragar powder has not been previously reported as a catalyst for the synthesis of 6-methyl-4-phenylcarbamoyl-1,2,3,4 tetrahydropyrimidine-2-ones under ultrasonic condition (Scheme 1). This method not only preserves the simplicity of Biginelli's one-pot procedure but also remarkably improves the yields (> 90\%) of dihydropyrimidinones synthesis in shorter reaction time. Dihydropyrimidinones obtained were tested for their antibacterial and antituberculosis activity.

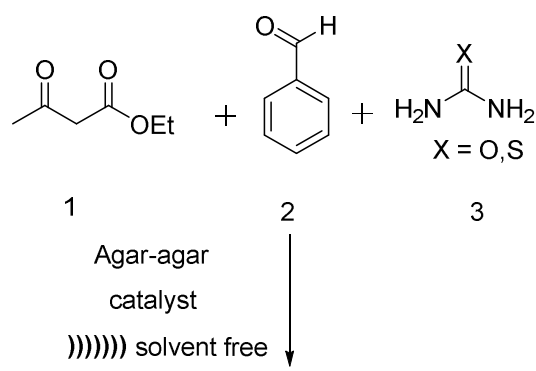<smiles>[X]C1=NC(c2ccccc2)C(C(=O)OCC)=C(C)N1</smiles>

Scheme 1. Agar catalyzed synthesis of 3,4dihydropyrimidinones under ultrasound irradiation.

\section{MATERIALS AND METHOD}

All the reagents were purchased from Merck and Loba and were used without further purification except benzaldehyde, for which a freshly distilled sample was used. Agar powder was purchased from Across Organics and used without any post modification. The melting points were measured in an open capillary. FT-IR spectra were recorded as $\mathrm{KBr}$ pellets on Shimadzu FTIR- 8400s spectrometer. ${ }^{1} \mathrm{HNMR}$ was recorded on a Bruker $400 \mathrm{MHz}$ spectrometer. Reactions were monitored by thin layer chromatography (TLC) on Merck's silica gel plates (60 F254), visualizing with ultraviolet light. Ultrasonicator of technical specifications is as Electric supply: $230 \mathrm{~V}$, Ultrasonic frequency: $33 \mathrm{KHz}$, Ultrasonic processor power: 100 Watts.

The derivatives were subjected to docking studies to evaluate the interaction with 3-oqoacyl-(Acyl-carrier-protein) reductase of Mycobacterium tuberculosis H37v. All computations data were performed on Pentium (R) DualCore CPUE5500@ $2.80 \mathrm{HGz}$ with memory $(\mathrm{RAM})=2.00$ GB and docking was done by using V Life Science software.
Staphylococcus aureus, Bacillus subtilis, Escherichia coli, P. aeruginosa were obtained from the microbiology department, Savitribai Phule Pune University, Pune. All the strains were maintained on nutrient agar medium.

\section{EXPERIMENTAL:}

\subsection{Synthesis}

Synthesis of 6 -methyl, 4-phenyl carbamoyl-1, 2, 3, 4 tetrahydropyrimidine-2-ones

A mixture of an aldehyde ( $1 \mathrm{mmol})$, ethyl acetoacetate $(1.2$ mmole $)$, urea/ thiourea $(1.5 \mathrm{mmol})$ and agar powder $(0.020$ g) was irradiated in ultrasonicator. The reaction was monitored by TLC. After completion of the reaction, the mixture was poured into water and the crude product was collected as a precipitate and washed with cold ethyl acetate.

\section{Spectral data of selected compounds}

5-Ethoxycarbonyl-6-methyl-4-phenyl-3,4-dihydropyrimidin2(1H)-one (4a) m.p. $202-205^{\circ} \mathrm{C}$. IR $(\mathrm{KBr})=v$ 3245, 3118, $2978,1725,1701,1649 \mathrm{~cm}^{-1}$.

${ }^{1} \mathrm{H}$ NMR (400 MHz, DMSO-d $\left.{ }_{6}\right) \delta: 1.10(\mathrm{t}, 3 \mathrm{H}, \mathrm{J}=6.9 \mathrm{~Hz}$, $\left.\mathrm{OCH}_{2} \mathrm{CH}_{3}\right), 2.24\left(\mathrm{~s}, 3 \mathrm{H}, \mathrm{CH}_{3}\right), 4.06(\mathrm{q}, 2 \mathrm{H}, \mathrm{J}=6.9 \mathrm{~Hz}$, $\left.\mathrm{OCH}_{2} \mathrm{CH}_{3}\right), 5.12$ (s, $\left.1 \mathrm{H}, \mathrm{C}(4)-\mathrm{H}\right), 7.26-7.30\left(\mathrm{~m}, 5 \mathrm{H}, \mathrm{C}_{6} \mathrm{H}_{5}\right)$, $7.82(\mathrm{~s}, 1 \mathrm{H}, \mathrm{NH}), 9.11(\mathrm{~s}, 1 \mathrm{H}, \mathrm{NH})$

5-Ethoxycarbonyl-4-(4-chlorophenyl)-6-methyl-3,4dihydropyrimidin-2(1H)-one (4b) m.p. $211-213^{\circ} \mathrm{C}$

${ }^{1} \mathrm{H}$ NMR (400 MHz, DMSO- $\left.\mathrm{d}_{6}\right) \delta: 1.12(\mathrm{t}, 3 \mathrm{H}, \mathrm{J}=7.1 \mathrm{~Hz}$, $\left.\mathrm{OCH}_{2} \mathrm{CH}_{3}\right), 2.30\left(\mathrm{~s}, 3 \mathrm{H}, \mathrm{CH}_{3}\right), 3.91(\mathrm{q}, 2 \mathrm{H}, \mathrm{J}=7.1 \mathrm{~Hz}$, $\left.\mathrm{OCH}_{2} \mathrm{CH}_{3}\right), 5.07(\mathrm{~d}, 1 \mathrm{H}, \mathrm{J}=2.3 \mathrm{~Hz}, \mathrm{CH}), 7.21(\mathrm{~d}, 2 \mathrm{H}, \mathrm{J}=9.2$, Ar-H), 7.69 (d, 2H, J=9.2, Ar-H), 7.94(s, 1H, NH)

5-Ethoxycarbonyl-4-(4-methoxy)-6-methyl-3,4dihydropyrimidin-2(1H)-one (4f) m.p. $203-207^{\circ} \mathrm{C}$. $\mathrm{IR}(\mathrm{KBr})=v$ 3436, 3247, 3113, 2929, 1724, 1705, 1649 $\mathrm{cm}^{-1}$.

${ }^{1} \mathrm{H}$ NMR (400 MHz, DMSO- $\left.\mathrm{d}_{6}\right) \delta: 1.10(\mathrm{t}, 3 \mathrm{H}, \mathrm{J}=7.0 \mathrm{~Hz}$, $\left.\mathrm{CH}_{2} \mathrm{CH}_{3}\right), 2.25$ (s, $\left.3 \mathrm{H}, \mathrm{CH}_{3}\right), 3.70$ (s, $\left.3 \mathrm{H}, \mathrm{OCH}_{3}\right), 3.90-4.10$ (q, $\left.2 \mathrm{H}, \mathrm{J}=7.0 \mathrm{~Hz}, \mathrm{CH}_{2} \mathrm{CH}_{3}\right), 5.60(\mathrm{~d}, 1 \mathrm{H}, \mathrm{J}=2.3 \mathrm{~Hz}, \mathrm{C}(4)-\mathrm{H})$, 6.80-6.90 (d, 2H, J=7.2 Hz, Ar-H), 7.15-7.25 (d, 2H, J=7.2 $\mathrm{Hz}, \mathrm{Ar}-\mathrm{H}$ ), 7.65 (brs, 1H, NH), 9.17 (brs, 1H, NH)

5-Ethoxycarbonyl-4-(4-nitro-phenyl)-6-methyl-3,4dihydropyrimidin-2(1H)-one (4g) m.p. $234-236^{\circ} \mathrm{C}$.

${ }^{1} \mathrm{H}$ NMR $\left(400 \mathrm{MHz}, \mathrm{CDCl}_{3}\right) \delta: 1.1(\mathrm{t}, 3 \mathrm{H}, \mathrm{J}=6.9 \mathrm{~Hz}$, $\left.\mathrm{OCH}_{2} \mathrm{CH}_{3}\right), 2.27\left(\mathrm{~s}, 3 \mathrm{H}, \mathrm{CH}_{3}\right), 3.98(\mathrm{q}, 2 \mathrm{H}, \mathrm{J}=6.9 \mathrm{~Hz}$, $\left.\mathrm{OCH}_{2} \mathrm{CH}_{3}\right), 5.30(\mathrm{~d}, 1 \mathrm{H}, \mathrm{J}=2.3 \mathrm{~Hz}, \mathrm{C}(4)-\mathrm{H}), 7.51(\mathrm{~d}, 2 \mathrm{H}$, $\mathrm{J}=8.4 \mathrm{~Hz}, \operatorname{Ar}-\mathrm{H}), 7.89(\mathrm{~s}, 1 \mathrm{H}, \mathrm{NH}), 8.22(\mathrm{~d}, 2 \mathrm{H}, \mathrm{J}=8.4 \mathrm{~Hz}$, Ar-H), 9.37 (s, 1H, NH).

5-Ethoxycarbonyl-6-methyl-4-cinnamyl-3,4dihydropyrimidin-2(1H)-one (4h) m.p.230-236 ${ }^{\circ} \mathrm{C}$.

${ }^{1} \mathrm{H}$ NMR (400 MHz, DMSO-d $) \delta: 1.20(\mathrm{t}, 3 \mathrm{H}, \mathrm{J}=6.9 \mathrm{~Hz}$, $\left.\mathrm{OCH}_{2} \mathrm{CH}_{3}\right), 2.23\left(\mathrm{~s}, 3 \mathrm{H}, \mathrm{CH}_{3}\right), 4.10(\mathrm{q}, 2 \mathrm{H}, \mathrm{J}=6.9 \mathrm{~Hz}$, $\left.\mathrm{OCH}_{2} \mathrm{CH}_{3}\right), 4.85(\mathrm{~d}, 1 \mathrm{H}, \mathrm{J}=2.8 \mathrm{~Hz}, \mathrm{C}(4)-\mathrm{H}), 6.2(\mathrm{~d}, 1 \mathrm{H}$, 
$\mathrm{J}=5.9, \mathrm{CH}=\mathrm{CH}), 6.4(\mathrm{~d}, 1 \mathrm{H}, \mathrm{J}=15.8, \mathrm{CH}=\mathrm{CH}), 7.2(\mathrm{~m}, 5 \mathrm{H}$, Ar-H), 9.5 (brs, 1H, NH), 10.2 (brs, 1H, NH).

5-Ethoxycarbonyl-4-(thiophen-2-yl)-6-methyl-3,4 dihydropyrimidin-2(1H)-one (4i) m.p. $210-213^{\circ} \mathrm{C}$.

${ }^{1} \mathrm{H}$ NMR (400 MHz, DMSO- $\mathrm{d}_{6}$ ) $\delta: 1.29(\mathrm{t}, 3 \mathrm{H}, \mathrm{J}=6.9 \mathrm{~Hz}$, $\mathrm{OCH}_{2} \mathrm{CH}_{3}$ ), 4.20 (q, 2H, J=6.7hz, $\left.\mathrm{OCH}_{2} \mathrm{CH}_{3}\right), 2.26$ (s, 3H, vinyl methyl), 5.41 (d, $1 \mathrm{H}, \mathrm{CH}=\mathrm{CH}), 6.8-7.4(\mathrm{Ar}-\mathrm{H}$ thienyl ring), 7.65 (brs, 1H, NH), 9.17 (brs, $1 \mathrm{H}, \mathrm{NH}$ ).

5-Ethoxycarbonyl-4-(4-N(CH3)2)1-6-methyldihydropyrimidin-2(1H)-one $(\mathbf{4 j})$ m.p. $256-258^{\circ} \mathrm{C}$.

${ }^{1} \mathrm{H}$ NMR (400 MHz, DMSO- d6)) $\delta: 1.18(\mathrm{t}, 3 \mathrm{H}, \mathrm{J}=7.6 \mathrm{~Hz}$, CH3), 2.4 (s, 3H, CH3), 2.8 (s, 6H, N(CH3)2), 4.00 (q, 2H, $\mathrm{J}=7.6 \mathrm{~Hz}, \mathrm{OCH} 2 \mathrm{CH} 3), 5.02(\mathrm{~d}, 1 \mathrm{H}, \mathrm{C}(4)-\mathrm{H}), 6.6(\mathrm{~d}, 2 \mathrm{H}$, $\mathrm{J}=9.1 \mathrm{~Hz}, \mathrm{Ar}-\mathrm{H}), 7.00(\mathrm{~d}, 2 \mathrm{H}, \mathrm{J}=9.1 \mathrm{~Hz}, \mathrm{Ar}-\mathrm{H}), 7.6$ and 9.16 (2 brs, $2 \mathrm{H}, \mathrm{NH}$ );

5-Ethoxycarbonyl-4-(4-hydroxyphenyl)-6-methyl-3,4dihydropyrimidin-2(1H)-one (4k) m.p. $230-232^{\circ} \mathrm{C}$.

${ }^{1} \mathrm{H}$ NMR (400 MHz, DMSO- $\mathrm{d}_{6}$ ) $\delta: 1.09$ (t, 3H, J=7.1 Hz, $\mathrm{CH}_{2} \mathrm{CH}_{3}$ ), 2.22 (s, 3H, CH ), 3.97 (q, 2H, J=7.1 Hz, $\mathrm{OCH}_{2}$ ), $5.03(\mathrm{~d}, 1 \mathrm{H}, \mathrm{J}=2.9 \mathrm{~Hz}, \mathrm{C}(4)-\mathrm{H}), 6.67$ (d, 2H, Ar-H), 7.6 (brs,$\mathrm{OH}), 7.02(\mathrm{~d}, 2 \mathrm{H}, \mathrm{Ar}-\mathrm{H}), 7.57$ (bs, 1H, NH), 9.06 (bs, 1H, $\mathrm{NH})$.

\subsection{Antibacterial Activity:}

Antibacterial activity of the compounds was determined by the well diffusion method [24]. The microbial cultures were grown at $37{ }^{\circ} \mathrm{C}$ for $18 \mathrm{~h}$ and then diluted by sterile saline $(0.9 \% \mathrm{w} / \mathrm{v})$ solution to obtain a cell suspension of 105 $\mathrm{CFU} / \mathrm{ml}$. Diluted inoculum $(0.2 \mathrm{ml}, 105 \mathrm{CFU} / \mathrm{ml})$ of test organism was spread on nutrient agar plates. Test compounds and standard were dissolved in dimethyl sulfoxide (DMSO). Different concentration for the test compounds in the range of $10,20,30,40,50$, and $100 \mu \mathrm{g} / \mathrm{ml}$ were prepared. Wells of $6 \mathrm{~mm}$ diameter were punched into the agar medium and filled with $20 \mu \mathrm{l}$ of test compound. The plates were incubated for $18-24 \mathrm{~h}$ at $37^{\circ} \mathrm{C}$. The antibiotic ciprofloxacin at $10 \mu \mathrm{g} / \mathrm{ml}$ was used in the test system as positive control.

All the tests were performed under sterile conditions and repeated three times.

\subsection{Antimycobacterial Activity:}

The antimycobacterial activity of the synthesized compounds was performed as per conventional $\mathrm{L} \mathrm{J}$ method [25]. Isoniazid was used as a positive control of growth inhibition using stock solutions (10 mg/mL, HiMedia). Compounds were dissolved in DMSO in various concentrations of $1000 \mu \mathrm{g} / \mathrm{ml}, \quad 500 \mu \mathrm{g} / \mathrm{ml}, \quad 250 \mu \mathrm{g} / \mathrm{ml}$, $100 \mu \mathrm{g} / \mathrm{ml}, 62.5 \mu \mathrm{g} / \mathrm{ml}, 50 \mu \mathrm{g} / \mathrm{ml}, 25 \mu \mathrm{g} / \mathrm{ml}, 12.5 \mu \mathrm{g} / \mathrm{ml}, 6.25$ $\mu \mathrm{g} / \mathrm{ml}, 3.25 \mu \mathrm{g} / \mathrm{ml}$. Additional controls, DMSO (solvent without compound) and medium without inoculums, were included in all the assay plates avoiding intra assay variability. The results were analyzed as the percentage of growth inhibition.

\section{RESULTS AND DISCUSSIONS:}

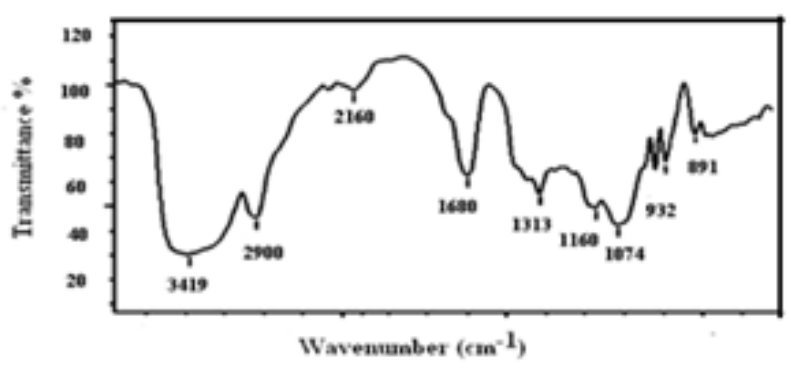

FIGURE 1. FTIR OF AGAR-CATALYST

Figure 1 shows the characteristic bands for agar-catalyst. FTIR of agar-agar shows broad peaks at $\sim 3419 \mathrm{~cm}-1$ due to $\mathrm{OH}$ group. The peak at $\sim 1074 \mathrm{~cm}-1$ and $\sim 932 \mathrm{~cm}-1$ are associated with the 3, 6-anhydrogalactose bridges, while the peak at $\sim 2900 \mathrm{~cm}-1$ is attributed to methoxyl groups. The band around $1680 \mathrm{~cm}-1$ is due to the stretching of the conjugated peptide bond formed by amine (-NH) .

\subsection{Synthesis}

To optimize the reaction conditions for the formation of the target compounds, we used benzaldehyde $(1 \mathrm{mmol})$, ethyl acetoacetate $(1 \mathrm{mmol})$ and urea $(1.5 \mathrm{mmol})$ as model substrates. Various organic acid catalyst were investigated for the model reaction. The results of these comparative experiments are reported in Table 1. Chloroacetic acid and citric acid catalyzed reactions give the desire product in around $67 \%$ yield within 30-40 min time. (Table 1, entries 2, 5). Under the ultrasonic conditions, it was gratifying to observe that more than $90 \%$ yield of the desired product $\mathbf{4 a}$ was obtained when the agar powder was used as a catalyst (Table 1, entry 7). This indicates that agar works more efficiently than organic acids. In order to improve the yield, we performed the experiments with different ratios of aldehyde with $\beta$-keto ester and urea/thiourea. Molar ratio of 1:1:1.5 reactants afforded the best results (Table 1 ).

Table 1. Synthesis of 6-methyl-4-phenyl carbamoyl-1, 2, 3, 4 tetrahydropyrimidine-2-one $\mathbf{4 a}$ using different catalysts.

\begin{tabular}{|c|c|c|c|}
\hline Entry & Catalyst & $\begin{array}{c}\text { Time } \\
(\mathrm{min})\end{array}$ & Yield $^{\mathrm{a}}$ \\
\hline 1 & Acetic acid & 40 & $72 \%$ \\
\hline 2 & Chloroacetic acid & 35 & $65 \%$ \\
\hline 3 & Oxalic acid & 40 & $70 \%$ \\
\hline 4 & Tartaric acid & 35 & $75 \%$ \\
\hline 5 & Citric acid & 38 & $68 \%$ \\
\hline 6 & Ascorbic acid & 40 & $78 \%$ \\
\hline 7 & Agar & 30 & $92 \%$ \\
\hline
\end{tabular}

The catalytic activity of agar catalyst was studied by varying the catalyst amount from $0.005 \mathrm{~g}$ to $0.030 \mathrm{~g}$ (Table 2). Increasing catalyst amount the yield of the reaction increased from $70 \%$ to $92 \%$ respectively. With higher catalyst amount $(>0.020 \mathrm{~g})$ the yield of the product was around $92 \%$, 
indicating that further increase in catalyst amount did not show any appreciable enhancement in the yield of the desired product. Thus, it was concluded that agar provides a best catalytic medium for this multicomponent reaction.

Table 2. Optimization of amount of agar catalyst for the synthesis of 6-methyl-4-phenyl carbamoyl-1,2,3,4 tetrahydropyrimidine-2-one $\mathbf{4 a}$.

\begin{tabular}{|c|c|c|}
\hline Entry & Amount Catalyst (g) & Yield $^{\mathrm{a}}$ \\
\hline 1 & 0.005 & $70 \%$ \\
\hline 2 & 0.010 & $83 \%$ \\
\hline 3 & 0.015 & $87 \%$ \\
\hline 4 & 0.020 & $92 \%$ \\
\hline 5 & 0.025 & $92 \%$ \\
\hline 6 & 0.030 & $92 \%$ \\
\hline
\end{tabular}

Reaction Conditions: Benzaldehyde (1 mmol), ethylacetoacetate (1 $\mathrm{mmol})$, urea $(1.5 \mathrm{mmol})$, catalyst $(\mathrm{g})$ were sonicated for $30 \mathrm{~min}$.

${ }^{a}$ Isolated yield after recrystallization

Effect of different temperatures and ultrasonic conditions on DHPM synthesis was also studied on the model reaction of benzaldehyde, ethyl acetoacetate and urea. The obtained result showed that the reaction carried out in ultrasound condition $\left(45^{\circ} \mathrm{C}\right)$ gives better yields (Table 3 , entry 2 ) in a shorter reaction time compared to heating at $100^{\circ} \mathrm{C}$ and $120^{\circ} \mathrm{C}$ (Table 3 , entry 3,4 ).

Table 3 Optimization of reaction temperature on the synthesis of DHPM

\begin{tabular}{|l|l|l|l|}
\hline Entry & Temp $\left({ }^{\circ} \mathrm{C}\right)$ & Time $(\mathrm{h})$ & Yield \\
\hline 1 & 30 & 8 & $20 \%$ \\
\hline 2 & 45 & 0.5 & $91 \%$ \\
\hline 3 & 100 & 4 & $80 \%$ \\
\hline 4 & 120 & 2 & $85 \%$ \\
\hline
\end{tabular}

Reaction Conditions: Benzaldehyde (1 mmol), ethylacetoacetate $(1.2 \mathrm{mmol})$, urea $(1.5 \mathrm{mmol})$, agar -agar powder $(0.020 \mathrm{~g})$

We subsequently applied the optimized reaction conditions to various substituted aldehydes to explore the applicability of the reaction system. It is worth to note that Biginelli reactions produced excellent yields for a wide range of aromatic aldehydes bearing electron-donating substituents (Table 4, entries 2-6, 10, 11) as compared to electro withdrawing substituents (Table 4, entries 7, 8). Cinnamaldehyde and 2-thienylaldehyde also worked well under optimized condition without side product formation. Substituted thiourea also reacted in a similar manner with good yield. (Table 4, entry 5). The superiority of the use of ultrasonication irradiation for the DHPM synthesis over reported methods is significant. This method provides an easy, eco-friendly mild reaction protocol for DHPM synthesis.

All the DHPM derivatives were characterized by spectral analysis The probable mechanism for the DHPM synthesis is shown in Scheme 2. The reaction may proceed through the activation of the carbonyl group by hydroxy group of agar catalyst to generate an acyl amine intermediate which further reacts with ethyl acetoacetate producing an open chain ureide. Ureide on subsequent cyclization with dehydration gives dihydropyrimidinone.

Table 4. Agar catalyzed 1, 2, 3, 4 tetrahydropyrimidine-2ones synthesis using an ultrasound condition.

\begin{tabular}{|c|c|c|c|c|c|}
\hline Entry & Cpd & Ar-CHO & X & $\begin{array}{c}\text { Time } \\
(m i n)\end{array}$ & $\begin{array}{c}\text { Yield } \\
(\%)\end{array}$ \\
\hline 1 & $4 \mathrm{a}$ & $\mathrm{Ph}$ & $\mathrm{O}$ & 30 & $91(78)^{\mathrm{a}}$ \\
\hline 2 & $4 \mathrm{~b}$ & $4-\mathrm{ClC}_{6} \mathrm{H}_{4}$ & $\mathrm{O}$ & 27 & $90(78)^{\mathrm{a}}$ \\
\hline 3 & $4 \mathrm{c}$ & $4-\mathrm{BrC}_{6} \mathrm{H}_{4}$ & $\mathrm{O}$ & 24 & 91 \\
\hline 4 & $4 \mathrm{~d}$ & $4-\mathrm{FC}_{6} \mathrm{H}_{4}$ & $\mathrm{O}$ & 32 & 85 \\
\hline 5 & $4 \mathrm{e}$ & $4-\mathrm{BrC}_{6} \mathrm{H}_{4}$ & $\mathrm{~S}$ & 35 & 90 \\
\hline 6 & $4 \mathrm{f}$ & $4-\mathrm{MeOC}_{6} \mathrm{H}_{4}$ & $\mathrm{O}$ & 22 & $95(61)^{\mathrm{a}}$ \\
\hline 7 & $4 \mathrm{~g}$ & $4-\mathrm{NO}_{2} \mathrm{C}_{6} \mathrm{H}_{4}$ & $\mathrm{O}$ & 55 & $85(58)^{\mathrm{a}}$ \\
\hline 8 & $4 \mathrm{~h}$ & $\mathrm{C}_{6} \mathrm{H}_{5} \mathrm{CH}=\mathrm{CH}_{\mathrm{H}}$ & $\mathrm{O}$ & 32 & 90 \\
\hline 9 & $4 \mathrm{i}$ & $2-\mathrm{Thienyl}_{4}$ & $\mathrm{O}$ & 40 & 88 \\
\hline 10 & $4 \mathrm{j}$ & $\mathrm{N}(\mathrm{Me})_{2}-\mathrm{C}_{6} \mathrm{H}_{4}$ & $\mathrm{O}$ & 22 & 93 \\
\hline 11 & $4 \mathrm{k}$ & $4-\mathrm{OH} \mathrm{C}_{6} \mathrm{H}_{4}$ & $\mathrm{O}$ & 26 & $89(67)^{\mathrm{a}}$ \\
\hline
\end{tabular}

Isolated Yield: ${ }^{a}$ Classical Biginelli conditions (cat $\mathrm{HCl}$ in $\mathrm{EtOH}$, reflux, $18 \mathrm{~h})$. Reaction conditions: Aldehyde (1 mmol), ethylacetoacetate $(1.2 \mathrm{mmol})$, urea $(1.5 \mathrm{mmol})$, agar powder $(0.020$ g)

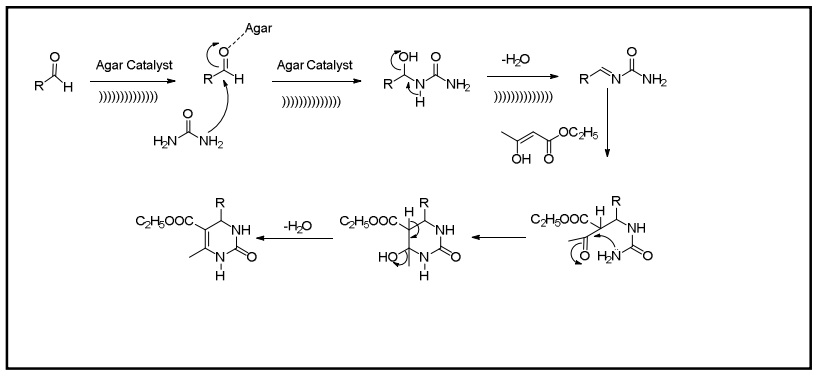

Scheme 2. Probable mechanism of agar catalyzed DHPM synthesis

\subsection{Antibacterial activity}

The compounds were tested against Staphylococcus aureus, Bacillus subtilis, Escherichia coli and P. aeruginosa. Most of the compounds showed mild anti-bacterial activity. However, a significant activity was observed for electron donating group containing compounds $\mathbf{4 d}, \mathbf{4 i}$ and $\mathbf{4 k}$ at 50 $\mu \mathrm{g} / \mathrm{ml}$. (Table 6, entries 3, 5 and 6) Compounds bearing as substituents fluorine, thiophene aldehyde and $-\mathrm{OH}$ were found to be active against both the Gram + and Gram bacteria. The antibacterial activity was compared with the standard ciprofloxacin (Table 6). 
Table 6. Antibacterial activity of 6-methyl-4phenylcarbamoyl-1, 2, 3, 4 tetrahydropyrimidine-2-ones (50 $\mu \mathrm{g} / \mathrm{ml}$.)

\begin{tabular}{|c|c|c|c|c|c|}
\hline $\begin{array}{c}\text { Sr. } \\
\text { No }\end{array}$ & Cpd & $\begin{array}{c}S . \\
\text { aureus }\end{array}$ & $\begin{array}{l}\text { B. } \\
\text { Subtilis }\end{array}$ & $\begin{array}{l}\text { E. } \\
\text { coli }\end{array}$ & $\begin{array}{c}\text { P. } \\
\text { aeruginosa }\end{array}$ \\
\hline & & $\begin{array}{c}\text { Zone of inhibition } \\
(\mathrm{mm})\end{array}$ & \multicolumn{2}{|c|}{$\begin{array}{c}\text { Zone of inhibition } \\
\text { (mm) }\end{array}$} \\
\hline 1 & $4 \mathrm{~b}$ & 08 & 13 & 10 & 12 \\
\hline 2 & $4 \mathrm{c}$ & 11 & 10 & 08 & 07 \\
\hline 3 & $4 \mathrm{~d}$ & 22 & 26 & 24 & 21 \\
\hline 4 & $4 \mathrm{e}$ & 10 & 13 & 06 & 04 \\
\hline 5 & $4 \mathrm{i}$ & 25 & 28 & 22 & 23 \\
\hline 6 & $4 \mathrm{k}$ & 24 & 25 & 25 & 20 \\
\hline 7 & $\begin{array}{c}\text { Ciproflo } \\
\text { xacin }\end{array}$ & 28 & 30 & & \\
\hline
\end{tabular}

\subsection{Antimycobacterial activity}

The antimycobacterial activity of the synthesized compounds was performed as per conventional L J method [25]. Isoniazid was used as a positive control of growth inhibition using stock solutions (10 mg/mL, HiMedia). Compounds were dissolved in DMSO in various concentrations of $1000 \mu \mathrm{g} / \mathrm{ml}, 500 \mu \mathrm{g} / \mathrm{ml}, 250 \mu \mathrm{g} / \mathrm{ml}, 100 \mu \mathrm{g} / \mathrm{ml}, 62.5 \mu \mathrm{g} / \mathrm{ml}$, $50 \mu \mathrm{g} / \mathrm{ml}, \quad 25 \mu \mathrm{g} / \mathrm{ml}, \quad 12.5 \mu \mathrm{g} / \mathrm{ml}, \quad 6.25 \mu \mathrm{g} / \mathrm{ml}, \quad 3.25 \mu \mathrm{g} / \mathrm{ml}$. Additional controls, DMSO (solvent without compound) and medium without inoculums, were included in all the assay plates avoiding intra assay variability. The results were analyzed as the percentage of growth inhibition. Synthesized compounds showed weak activity. However, compound $4 \mathrm{f}$ showed significant antituberculosis activity at $12.5 \mu \mathrm{g} / \mathrm{ml}$ and can can be considered a promising scaffold for the development of antituberculosis compounds.

\subsection{Docking studies}

The compounds were studies for their docking interactions with the mycobacterium target protein H37Rv. It has been observed that methoxy substituted dihydropyrimidinones exhibited better interactions with amino acids residues in the active site of NADH-dependent enoyl-ACP reductase enzyme. The $\mathrm{NH}$ group and methoxy group on dihydropyrimidinone ring show better hydrophobic and hydrogen bond interactions. Figure 2 shows hydrophobic interaction of one compound 4 fwith the targeted protein H37Rv. In general, the electron donating substituents on this ring seem to increase the interaction of the compounds with the protein.

\section{CONCLUSION}

We have developed a new simple, efficient and environmentally benign method for the synthesis of dihydropyrimidinones by using agar as a renewable biopolymer. Low loading of catalyst, short reaction times and operational simplicity are the important features of this methodology. Some of the synthesized compounds with electron donating groups showed promising broad spectrum antibacterial activity. One of the dihydropyrimidinone showed promising anti-tuberculosis activity. This synthetic methodology is useful for green synthesis of various dihydropyrimidinone derivatives which can be used against infectious diseases in future.

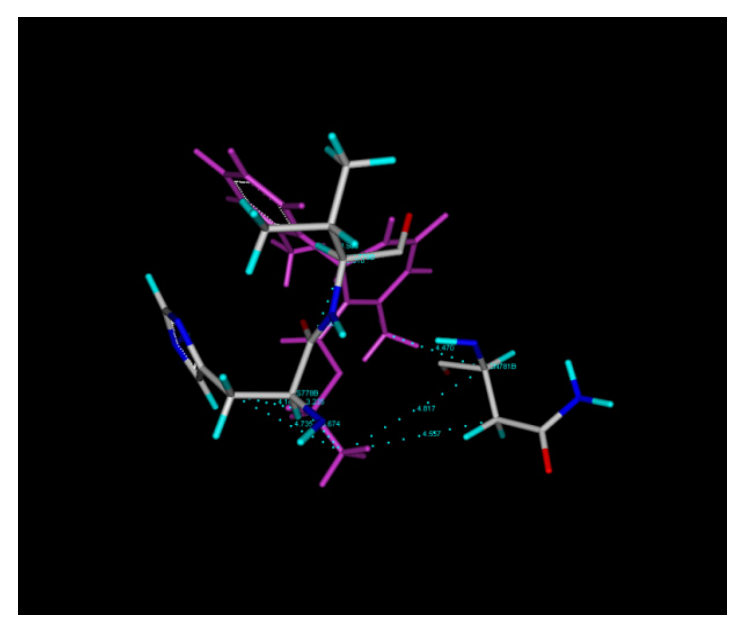

Figure 2. Hydrophobic bond interactions of compound $\mathbf{4 f}$.

\section{ACKNOWLEDGEMENTS}

Authors are thankful to Nowrosjee Wadia College, Pune and MAEER's Maharashtra Institute of Pharmacy Pune for research laboratory facilities. The authors thank the Board of College and University Development (BCUD), S. P. Pune University, Pune, ISRO and Department of Science and Technology (DST) for providing financial assistance.

\section{REFERENCES}

[1] Salehi, H.; Guo, Q. A Facile and Efficient One-Pot Synthesis of Dihydropyrimidinones Catalyzed by Magnesium Bromide Under Solvent-Free Conditions. Synth. Commun. 2004, 34(1), 171-179.

[2] Nair, A.C.; Jayatilleke, P.; Wang, X.; William, M.S.; Welsh, J. Computational Studies on Tetrahydropyrimidine-2-one HIV-1 Protease Inhibitors: Improving Three-Dimensional Quantitative Structure-Activity Relationship Comparative Molecular Field Analysis Models by Inclusion of Calculated Inhibitor- and Receptor-Based Properties; J. Med. Chem., 2002, 45(4), 973-983.

[3] Ashok, M.; Holla, B.S.; Kumari, N.S. Convenient one pot synthesis of some novel derivatives of thiazolo [2,3-b] dihydropyrimidinone possessing 4-methylthiophenyl moiety and evaluation of their antibacterial and antifungal activities Eur. $J$. Med.Chem. 2007, 42(3), 380-385.

4. Bahekar, S.S.; Shinde, D.B. Synthesis and anti-inflammatory activity of some [4,6-(4-substituted aryl)-2-thioxo-1,2,3,4tetrahydro-pyrimidin-5-yl]-acetic acid derivatives. Biorganic and Medicinal chemistry Letters, 2004, 14(7),1733-1736.

5. Debache, A.; Boumoud, B.; Amimour, M.; Belfaitah, A.; Rhouati, S.; Carboni, B. Phenylboronic acid as a mild and efficient catalys for Biginelli reaction. Tetrahedron Lett. 2006, 47(32), 5697-5699.

6. Patil, A.D.; Kumar, N.V.; Kokke, W.C., Bean, M.F.; Freyer, A.J.; Brosse, C.D.; Mai, S.; Truneh, A.; Carte, B.; Novel Alkaloids from the Sponge Batzella sp.: Inhibitors of HIV gp120-Human CD4 Binding. J. Org. Chem., 1955, 60(5), 1182-1188. 
7. Kappe, C.O. Biologically active dihydropyrimidones of the Biginelli-type--a literature survey. Eur. J. Med. Chem., 2000, 35(12), 1043-1052.

8. A) Bhatewara, A.; Jetti, S.R.; Kadre, T.; Paliwal, P.; Jain, S. Microwave-Assisted Synthesis and Biological Evaluation of Dihydropyrimidinone Derivatives as Anti-Inflammatory, Antibacterial, and Antifungal Agents. Int. J. Med. Chem., 2013, 2013, Article ID 197612(5pages). B) Handore, K.; Walunj, D.; Chhattise, P.; Chabukswar, A.; Mohite, K.; Dallavalle, S.; Bahule, B.; Chabukswar, V. A novel route towards the ultrasound assisted synthesis of polyindole- $\mathrm{TiO}_{2}$ nanocomposite and evaluation of antibacterial activity. Polymer-Plastics Technology and Engineering. Published online $6^{\text {th }}$ July, 2017, DOI: 10.1080/03602559.2016.1163581.

9. Udwadia, Z.F.; Amale, R.A.; Ajbani, K.K.; Rodrigues, C. Totally drug resistant tuberculosis in India. Clin. Infect. Dis. 2012, 54(4), 579-581

10. Debjit, B.; Chiranjib; Chandira R.M.; Jayakar, B.; Kumar, K.P.S. Recent trends of drug used treatment of tuberculosis. J. Chem. Pharma. Res. 2009, 1(1): 113-133,

11. A) Upadhayaya, R.S.; Vandavasi, J.K.; Kardile, R.A.; Lahore, S.V.; Dixit, S.S.; Deokar, H.S.; Shinde, P.D; Sarmah, M.P. Chattopadhyaya, J. Novel quinoline and naphthalene derivatives as potent antimycobacterial agents. Eur. J. Med. Chem., 2010, 45(5), 1854-67. B) Chabukswar, A.; Kuchekar, B.; Lokhande, P.; Trambakye, M.; Pagare, B.; Kadam, V.; Jagdale, S.; Chabukswar V. Design, Synthesis and Evaluation of Antibacterial Activity of Novel Indazole Derivatives. Curr. Bio. Comp. 2013, 9, 263-269.

12. Murthy, J.M. Tuberculous meningitis: the challenges. Neurol. India. 2010, 58, 716-722.

13. Kappe C.O ; Falsone, S.F. Polyphosphate Ester-Mediated Synthesis of Dihydropyrimidines. Improved Conditions for the Biginelli Reaction. Syn. lett. 1998, 7, 718-720.

14. Nasr-Esfahani, M.; Hoseini, S.J.; Mohammadi, F. $\mathrm{Fe}_{3} \mathrm{O}_{4}$ Nanoparticles as an Efficient and Magnetically Recoverable Catalyst for the Synthesis of 3,4-Dihydropyrimidin-2(1H)-ones under Solvent-Free Conditions. Chinese Journal of catalysis. 2011, 32(9), 1484-1489.

15. Jain; S.L.; Joseph, J.K.; Sain, B. Ionic liquid promoted an improved synthesis of 3,4-dihydropyrimidinones using [bmim]BF4 immobilized $\mathrm{Cu}$ (II) acetylacetonate as recyclable catalytic system Catalysis Lett. 2007, 115(1-2), 52-55.

16. Chen, X.; Peng, Y. Chloroferrate(III) Ionic Liquid: Efficient and Recyclable Catalyst for Solvent-free Synthesis of 3,4Dihydropyrimidin-2(1H)-ones. Catalysis Lett. 2008, 122, 310-313.

17. Nakamura, H.; Matsui, Y. Silica Gel Nanotubes Obtained by the Sol-Gel Method J. Am.Chem. Soc. 1995, 117, 2651-2652.

18. Pozarentzi, M.; Stephanatou, J.S.; Tsoleridis, C.A. An efficient method for the synthesis of 1,5-benzodiazepine derivatives under microwave irradiation without solvent. Tetrahedron Lett. 2002 , 43(9), 1755-1758.

19. Garbe, T.R.; Kobayashi, M.; Shimizu, N.; Takesue, N., Ozawa, M.; Yukawa, H. Indolyl Carboxylic Acids by Condensation of Indoles with $\alpha$-Keto Acids. J. Nat. Prod. 2000, 63(5), 596-598.

20. Lal, J.; Gupta, S.K.; Agarwal, D.D; Chitosan: An efficient biodegradable and recyclable green catalyst for one-pot synthesis of 3,4-dihydropyrimidinones of curcumin in aqueous media Catalysis Communication. 2012, 27, 38-43.

21. DeCastro, C.; Primo, J.; Corma A. Heteropolyacids and large-pore zeolites as catalysts in acylation reactions using $\alpha, \beta$-unsaturated organic acids as acylating agents J. Mol. Catal. A: Chem. 1998, 134(1-3); 215-222.

22. Budarin, V.; Clark, J.H.; Deswarte, F.E.I.; Hardy, J.J.E.; Hunt, A. J.; Kerton F.M. Delicious not siliceous: Expanded carbohydrates as renewable separation media for column chromatography. Chem. Commun. 2005, 23, 2903-2905.

23. Horace H. Selby. Agar since 1943. Natural Plant Hydrocolloids, 1954, chapter 4, pp 16-19.

24. Yogi, P.; Ashid, M.; Hussain, N.; Khan, S.; Joshi, A. One-Pot Synthesis of Thiazoles via Hantzsch Thiazole Reaction and Their Antimicrobial Activity. Asian Journal of Chemistry, 2016; 28(4), 927-932.

25. Guzman, J.D.; Wube, A.; Evangelopoulos, D.; Gupta, A, Hüfner A.; Basavannacharya, C.; Rahman, M.M.; Thomaschitz, C.; Bauer R.; McHugh, T.D.; Nobeli, I.; Prieto, J.M.; Gibbons, S.; Bucar, F.; Bhakta, S. Interaction of N-methyl-2-alkenyl-4-quinolones with ATP-dependent MurE ligase of Mycobacterium tuberculosis: antibacterial activity, molecular docking and inhibition kinetics. $J$. Antimicrob. Chemother. 2011, 66(8), 1766-1772. 